\title{
Impact of Cooperative Team Environment and Procedural Justice on Work Environment Creativity: An Empirical Study of Banking Industry
}

\author{
Rubab Tahir* \\ Alhamd Islamic University, \\ Islamabad, Pakistan
}

\author{
Muhammad Razzaq Athar \\ Pir Mehr Ali Shah Arid Agriculture University, \\ Rawalpindi, Pakistan
}

\begin{abstract}
According to modern approaches to creativity, any human being can generate creative ideas, and it is not a genetic trait. Social setting, including teamwork, supervision, and surrounding environment, plays a significant role in determining an individual's creativity. This study will examine the role of social exchange factors in bringing work environment creativity empirically. For this reason, a questionnaire was distributed to be filled by a sample of 200 employees from the banking industry of Pakistan. Branches of 10 banks were selected in the vicinity of twin cities, i.e., Rawalpindi and Islamabad. Data collected from these bank branches were analyzed using statistical tests. Social exchange factors including procedural justice, cooperative team environment, and employee participation were studied. The mediating role of expert's knowledge sharing was assessed beside moderating role of adhocracy culture. It was concluded that adhocracy culture moderates the relationship of social exchange factors with work environment creativity. Moreover, expert's knowledge sharing mediates the relation of procedural justice and work environment creativity. This study will fill the gap by examining the factors affecting workplace creativity. This will help practitioners and researchers know the factors that affect workplace creativity, which will ultimately be beneficial for organizations.
\end{abstract}

Keywords: Work environment creativity, cooperative team environment, procedural justice

Received: 8 August 2018; Accepted: 4 September 2018; Published: 3 October 2018

\section{INTRODUCTION}

Innovation and creativity are necessary components for bringing and accelerating technical development and change process. Conventional wisdom is of the view that creativity is a trait which an individual has by its birth and it cannot be changed, improved or transferred. However recent researches suggest that every human brain can generate creative ideas though the level of wisdom or creativity varies according to a person's social setting, experiences, education, work group interaction and supervision etc. therefore modern approach argues that rate of creative performance can be influenced by social setting, supportive supervision and team interaction etc. at workplace such factors can be referred as social exchange factors. Research findings supports the argument that factors related to workplace environment has a tendency to influence employees' creativity (Amabile, Conti, Coon, Lazenby, \& Herron, 1996; Saputri \& Mulyaningsih, 2016). Creativity is regarded as an outcome in organizational behavior which includes services, products, work methods, business models or management processes which are useful and novel (Amabile, 1988; Bernik, Azis, Kartini, \& Harsanto, 2015; Shalley \& Gilson, 2004; Woodman, Sawyer, \& Griffin, 1993). This led to emphasis on creativity as an organizational outcome by which enables creativity to be quantified rather than a mental process which is difficult to be quantified (Amabile et al., 1996; Oetomo, Satrio, \& Lestariningsih, 2016). Therefore, creativity is examined by

${ }^{*}$ Correspondence concerning this article should be addressed to Rubab Tahir, Lecturer, Alhamd Islamic University, Islamabad, Pakistan. E-mail: rubabtahir.official@gmail.com

(c) 2018 The Author(s). Published by Informa KKG Publications. This is an Open Access article distributed under a Creative Commons Attribution-NonCommercial-NoDerivatives 4.0 International License which means that any user shall be free to copy and redistribute the material in any medium or format, provided that the use is for non-commercial purposes only, no modifications or adaptations are made. Also, original work is properly cited. 
scales to assess usefulness and novelty (Ayuningrat, Noermijati., \& Hadiwidjojo, 2016; Oldham \& Cummings, 1996; Tierney, Farmer, \& Graen, 1999; Zhou \& George, 2001). As suggested by previous researchers (Zhou \& Hoever, 2014). This study will extend the research on workplace creativity by examining variables identified by Schepers and Van den Berg (2007). The objectives of this study are as follows;

1: To examine the relationship of Cooperative Team Environment and Work Environment Creativity.

2: To examine the relationship of Procedural Justice and Work Environment Creativity.

3: To examine the role of Adhocracy Culture in the relationship of Cooperative Team Environment and Work Environment Creativity.

4: To examine the role of Adhocracy Culture in the relationship of Adhocracy Culture in the relationship of Procedural Justice and Work Environment Creativity.

5: To examine the role of Expert's Knowledge Sharing in the relation of Procedural Justice and Work Environment Creativity.

This study will fill the gap by examining the factors effecting workplace creativity. This will help practitioners and researchers in knowing the factors which effect the workplace creativity which will ultimately be beneficial for organizations. For future theorizing and research in this domain recommendations are given at the end of study.

\section{LITERATURE REVIEW}

Innovation, knowledge management and change management stems in organizational and employee creativity (Bhalerao, 2016; Ford \& Ogilvie, 1996). Trust and safety within the work group is claimed to be related to group creativity and innovation (West \& Anderson, 1996). According to Shalley and Gilson (2004) these factors include expert support, cooperative environment for work and autonomous nature of work. Moreover, work environment creativity and the ethical practices and values of organizations are found highly interconnected with creativity of employees. During economic recession it is found that organizations with more creativity in them are more capable of survival since it is also a competitive advantage. Literature on organizational behavior and innovation management is focused to identify factors for improving work environment creativity (Angriani, Ariffin, \& Rahmawati, 2017; Amabile et al., 1996; Zhou \& George, 2001). Current study will examine the relationship of social exchange factors with work environment creativity. Moreover, it will identify expert's knowledge sharing role in generating and sustain the work environment creativity.

Employee creativity and overall team creativity is found to be positively related with entrepreneurial leadership according to Cai, Lysova, Khapova, and Bossink (2018) and they found mediation of team creative efficacy and employee creative efficacy. They explained how workplace creativity is affected by entrepreneurial leadership.

Novelty which is beneficial for organizations is brought by work environment creativity at workplace. It is a tendency of employees to generate novel ideas in his/her work setting. It is important to not confuse innovation with creativity, as it is a characteristic of an individual to generate novel ideas which is not restricted to any knowledge area. Whereas innovation is novelty in one knowledge area (Stein, 1974). Three factors are argued to be affecting organizational creativity including abilities of employee, team characteristics, organizational characteristics. Organizational creativity is the goal in the approach of work environment creativity which results from these factors i.e., creative behaviors and creative situations. Environmental factors and social factors results in bringing creative behaviors of employee and teams within organizations (Woodman et al., 1993). As proposed by Amabile et al. (1996) the componential theory of creativity argues that creativity is dependent on two factors (1) within an individual, (2) outside the individual's personality. For the recent study the research framework is derived from the second perspective i.e., factors lying outside the individual's personality. Moreover, psychological perspective of work environment creativity is of mainly studied in this research and it is also supplemented with situated learning theory. For arousing social interactions cooperative team environment is effective according to Rousseau (1989). Organ (1997) claimed that organizational citizenship behavior is highly represented in cooperative team environment. For creating synergy and reliance among employees, cooperative team environment leads to work environment creativity which helps in knowledge management in the organizations. It also represents the culture prevailing in organizations according to Amabile componential theory of organizational creativity. The model proposed by Lind and Tyler (1988) suggests procedural justice to be relational such as status acknowledgement. Moreover, according to Thibaut and Walker (1975) procedural fairness is the participation and input level permitted by procedures (mostly referred as voice). Greenberg (1990) defined procedural justice as fair organizational processes of decision making and resource allocation. According to Leventhal, there are six 
characteristics of fair procedures including bias suppression, representativeness, ethicality, consistency, accuracy and correct ability. Age is an important factor in effecting the creativity levels of employee. Young employees according to a research were found to be more creative when they experience negative affect as compare to the mean score of negative affect (Volmer, Richter, \& Syrek, 2018). A research found positive relationship of employee creative performance with self-efficacy. whereas harmonious passion negatively moderates the relationship of workplace creativity and self-efficacy (Appu \& Sia, 2017). Moreover, Tang, Huang, and Wang (2017) found that marital satisfaction indirectly effects the workplace creativity through psychological resources spillover and it is found to be significant for low creative employees whereas those with high creative personalities were not significantly affected.

The exchange process between employee and an employer has one perspective known as psychological contract which has an implicit expectation of being treated fairly as argued by according to Rousseau (1989). Cameron and Quinn (1999) proposed a competing values framework offering four major organizational cultures i.e., stable hierarchy culture, cooperative team environment culture, rational culture and adhocracy culture. Adhocracy culture and cooperative team environment culture are examined in this study. As suggested by previous researchers (Zhou \& Hoever, 2014). This study will fill the gap by examining the factors effecting workplace creativity. This will help practitioners and researchers in knowing the factors which effect the workplace creativity which will ultimately be beneficial for organizations. So, the results of this study will be a part of large understanding of what effects workplace creativity forming the basis of actionable measures for organizational practitioners. The following model and hypothesis are developed in the light of situated learning theory.

\section{Hypotheses}

H1: Cooperative Team Environment is positively related to Work Environment Creativity.

H2: Procedural Justice is positively related to Work Environment Creativity.

H3: Adhocracy Culture positively moderates the relationship of Cooperative Team Environment and Work Environment Creativity.

H4: Adhocracy Culture positively moderates the relationship of Procedural Justice and Work Environment Creativity.

H5: Expert's Knowledge Sharing mediates the relation of Procedural Justice and Work Environment Creativity.

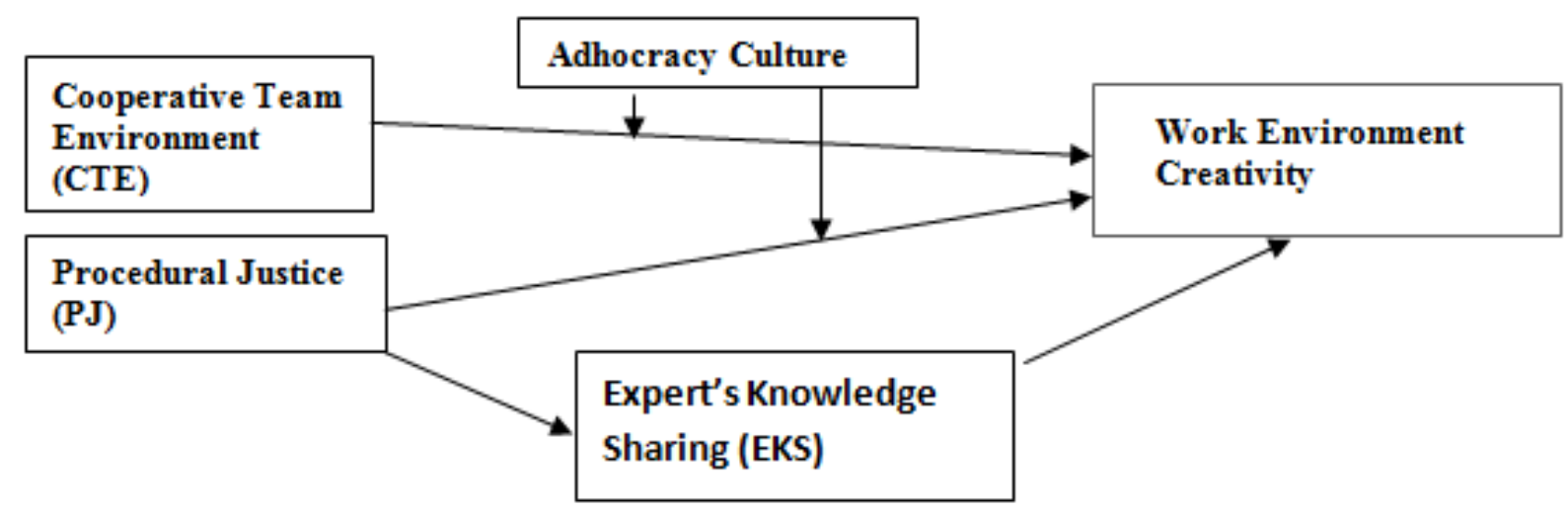

Figure 1 Theoretical Framework

\section{MEHODOLOGY}

To explore the relationships in this study a cross-sectional survey is conducted. Primary data was gathered by distributing questionnaire among the respondents. Questionnaire is used as a research instrument. It was comprised of 29 items and 5 points likert scale is used. Items were adopted from already developed scale by previous researchers. The creativity scale by Amabile et al. (1996) was used for work environment creativity. Cameron and Quinn (1999) scale of organizational Culture Assessment Instrument was used for cooperative team environment. Scale by Evers, van Vliet-Mulder, and Groot (2000) for employee participation was adopted. Moreover, Schepers and Van den Berg 
(2007) scale for expert's knowledge sharing was used. There were five items used for procedural justice measurement (Moorman, Niehoff, \& Organ, 1993).

For the recent study banking industry was the population for data collection survey. Non-probability convenient sampling was used for questionnaire distribution. Questionnaires were distributed among 150 employees of branches of 13 private banks located in the vicinity of two cities i.e., Rawalpindi and Islamabad. To test the reliability, Cronbach's Alpha is used. Confirmatory factor analysis is applied and correlation, linear regression was also tested. For mediation the Baron and Kenny method is used.

\section{RESULTS}

SPSS is used for data analysis as a statistical software. For calculating mean, median, mode and range of the data to see how many respondents participated in study, descriptive analysis was conducted. The response rate of this study is $100 \%$ as all the 200 respondents responded to the survey and filled their questionnaires. There were $52.0 \%$ male respondents and $48.0 \%$ female respondents who participated in the survey. Among them $32.0 \%$ were of age group 25 years and below, $54.5 \%$ were of age $26-40$ years, $12.5 \%$ were of $41-55$ years age and $3 \%$ were of 56 years and older than it. The alpha coefficient of procedural justice, cooperative team environment, expert's knowledge sharing, adhocracy culture and work environment creativity were $0.641,0.784,0.821,0.764$ and 0.758 respectively. These values fall in acceptable range of greater than 0.6 showing reliability of the measurement scale. Coefficient of correlation for procedural justice and cooperative team environment is 0.37 which is generally considered medium correlation, coefficient of correlation for adhocracy culture and cooperative team environment is 0.39 which is also medium correlation, for expert's knowledge sharing and cooperative team environment the coefficient of correlation is 0.192 which shows weak correlation. Moreover, coefficient of correlation for work environment creativity and cooperative team environment is 0.330 which is also a medium correlation.

Table 1 DEMOGRAPHICS STATISTICS

\begin{tabular}{lll}
\hline & Frequency & Percent \\
\hline Gender & & \\
Valid Male & 52 & 104 \\
Female & 48 & 96 \\
Total & 200 & 100 \\
Age & & \\
Valid 25 and below & 64 & 32 \\
$26-40$ & 105 & 52.5 \\
$41-55$ & 25 & 12.5 \\
$56-$ older & 06 & 3 \\
Total & 200 & 10 \\
\hline
\end{tabular}

Table 2 CORRELATION MATRIX

\begin{tabular}{llllll}
\hline & CTE & PJ & AC & EKS & WEC \\
\hline CTE & 1 & & & & \\
PJ & $.422^{* *}$ & 1 & & & \\
AC & $.501 * *$ & $.475^{* *}$ & 1 & & \\
EKS & $.452^{* *}$ & $.482^{* *}$ & $.422^{* *}$ & 1 & \\
WEC & $.472^{* *}$ & $.502^{* *}$ & $.422^{* *}$ & $.423^{* *}$ & 1 \\
\hline *. Correlation is significant at the 0.05 level (2-tailed). & & &
\end{tabular}

$* * *$. Correlation is significant at the 0.01 level (2-tailed). 
Table 3 REGRESSION STATISTICS

\begin{tabular}{lcccccc}
\hline Model & Sig $(p$-value $)$ & $t$-value & $R^{2}$ & $\beta$ & $F$ & $\begin{array}{l}\text { Durbin- } \\
\text { Watson }\end{array}$ \\
\hline Regression & .000 & 8.134 & .114 & .413 & 23.786 & 1.956 \\
\hline $\begin{array}{l}t>1.96, p<.05 \\
\text { Predictors: (Constant), Cooperative Team Environment } \\
\text { Dependent Variable: Work Environment Creativity }\end{array}$ & & & & \\
\end{tabular}

Since linear regression test is used to examine the relationship of cooperative team environment and work environment creativity. The result shows a significant relationship between them as $p$ value is 0.000 , its $t$ value is 8.134 and $F$ value is 23.786 . The $R$ square is 0.114 and the $\beta$ value shows positive relationship of cooperative team environment with work environment creativity. Durbin Watson is also 1.956 falling in the acceptable range of 1.5 to 2.5. Therefore, Hypothesis 1 is accepted.

Table 4 REGRESSION STATISTICS

\begin{tabular}{llccccl}
\hline Model & Sig $(p$-value $)$ & $t$-value & $R^{2}$ & $\beta$ & $F$ & $\begin{array}{l}\text { Durbin- } \\
\text { Watson }\end{array}$ \\
\hline Regression & .000 & 7.124 & .254 & .498 & 16.786 & 1.756 \\
\hline
\end{tabular}

$t>1.96, p<.05$

Predictors: (Constant), Procedural Justice

Dependent Variable: Work Environment Creativity

Results of linear regression to examine the relationship of procedural justice and work environment creativity shows a significant relationship between them as $p$ value is 0.000 , its $t$ value is 7.124 and $F$ value is 16.786 . The $R$ square is 0.254 and the $\beta$ value shows positive relationship of cooperative team environment with work environment creativity. Durbin Watson is also 1.756 falling in the acceptable range of 1.5 to 2.5. Hence, Hypothesis 2 is also accepted.

Table 5 REGRESSION STATISTICS

\begin{tabular}{llccccc}
\hline Model & Sig $(p$-value $)$ & $t$-value & $R^{2}$ & $\beta$ & $F$ & $\begin{array}{l}\text { Durbin- } \\
\text { Watson }\end{array}$ \\
\hline Regression $\quad .000$ & 7.224 & .124 & .455 & 16.489 & 1.766 \\
\hline $\begin{array}{l}t>1.96, p<.05 \\
\text { Predictors: (Constant), Adhocracy Culture } \\
\text { Dependent Variable: Work Environment Creativity }\end{array}$ & & & & \\
\hline
\end{tabular}

Table 6 MODERATION STATISTICS

\begin{tabular}{llccccl}
\hline Model & Sig $(p$-value $)$ & $t$-value & $R^{2}$ & $\beta$ & $F$ & $\begin{array}{l}\text { Durbin- } \\
\text { Watson }\end{array}$ \\
\hline Regression & .000 & 16.770 & .153 & .436 & 51.879 & 1.763 \\
\hline
\end{tabular}

a. Predictors: (Constant), Cooperative Team Environment, Moderator: Adhocracy Culture

b. Dependent Variable: Work Environment Creativity

To examine the Hypothesis 3, linear regression is used. Results show that relationship is significant as $p$ value is 0.000 and its $R$ square is 0.114 . Results also show that moderating variable i.e., adhocracy culture has a significant and positive relationship with work environment creativity. Then interaction term is created between independent variable i.e., cooperative team environment and moderating variable i.e., adhocracy culture, then it is regressed against 
dependent variable i.e., work environment creativity. Since cooperative team environment gives R square 0.114 i.e., it brought $11.4 \%$ change in work environment creativity and adhocracy culture shows $R$ square 0.124 i.e., it brought $12.4 \%$ change in work environment creativity. After interaction term regressed against work environment creativity it brought $15.3 \%$ change in work environment creativity, therefore results reveal that adhocracy culture moderates the relationship of cooperation team environment and work environment creativity. And $\beta$ value shows that it has positive moderating effect. Hence, this hypothesis is accepted.

Table 7 REGRESSION STATISTICS

\begin{tabular}{|c|c|c|c|c|c|c|}
\hline Model & Sig ( $p$-value) & $t$-value & $R^{2}$ & $\beta$ & $F$ & $\begin{array}{l}\text { Durbin- } \\
\text { Watson }\end{array}$ \\
\hline Regression & .000 & 7.224 & .124 & .455 & 16.489 & 1.766 \\
\hline
\end{tabular}

Table 8 8 MODERATION STATISTICS

\begin{tabular}{|c|c|c|c|c|c|c|}
\hline Model & Sig ( $p$-value) & $t$-value & $R^{2}$ & $\beta$ & $F$ & $\begin{array}{l}\text { Durbin- } \\
\text { Watson }\end{array}$ \\
\hline Regression & .000 & 16.235 & .353 & .417 & 52.679 & 1.764 \\
\hline
\end{tabular}

Results of Hypothesis 4 show that relationship of procedural justice and work environment creativity has $p$ value 0.000 so it is a significant relationship and its $R$ square is 0.254 . Results also reveal that the moderating variable which is adhocracy culture has a significant and positive relationship with work environment creativity. Then an interaction term of independent variable i.e., procedural justice and adhocracy culture which is a moderating variable is generated, the interaction term is regressed against work environment creativity. Since procedural justice has $R$ square 0.254 i.e., it brought $25.4 \%$ change in work environment creativity and adhocracy culture has $R$ square 0.124 i.e., it brought $12.4 \%$ change in work environment creativity. After regressing interaction term against work environment creativity, it brought $35.3 \%$ change in work environment creativity, therefore results reveal that adhocracy culture moderates the relationship of cooperation team environment and work environment creativity. And Beta value shows that it has positive moderating effect. So, this hypothesis is accepted.

Table 98 MODERATION STATISTICS

Multiple Regression Analysis Summary for PB, PP and CG

\begin{tabular}{|c|c|c|c|c|c|c|}
\hline Steps & $R^{2}$ & Adjusted $R^{2}$ & $f$ & B & $T$ & $\beta$ \\
\hline Step 1: & & & & & & \\
\hline $\mathrm{PJ}(\mathrm{IV}) \rightarrow \mathrm{WEC}(\mathrm{DV})$ & .254 & .145 & 16.786 & .498 & 7.124 & .432 \\
\hline Step 2: & & & & & & \\
\hline $\mathrm{PJ}(\mathrm{IV}) \rightarrow \mathrm{EKS}(\mathrm{MV})$ & .144 & .110 & 29.176 & 4.171 & 11.521 & .321 \\
\hline Step 3: & & & & & & \\
\hline $\mathrm{EKS}(\mathrm{MV}) \rightarrow \mathrm{WEC}(\mathrm{DV})$ & .135 & .212 & 74.020 & 1.270 & 4.311 & .433 \\
\hline Step 4: & & & & & & \\
\hline $\mathrm{PJ}(\mathrm{IV}) \rightarrow \mathrm{WEC}(\mathrm{DV})$ & .694 & .244 & 43.572 & .658 & 2.906 & .467 \\
\hline
\end{tabular}


Results of Hypothesis 5 show that mediating variable i.e., expert's knowledge sharing partially mediates the relation of procedural justice and work environment creativity. Therefore, Hypothesis 5 is accepted.

\section{DISCUSSION AND CONCLUSION}

The results of the statistical analysis show that Hypothesis 1,2, 3, 4 and 5 are true. Adhocracy culture positively moderates the relation of cooperative team environment with work environment creativity, and procedural justice with work environment creativity. Moreover, expert's knowledge sharing partially mediates the relation of procedural justice and work environment creativity. This research provides a broader understanding of team creativity at individual level by considering the social context and factors in account. Organizations need creative ideas in this era to cope in new ways with fierce competition and complex problems on daily basis where situation changes on a rapid pace. So contrary to previous research conducted by Schepers and Van den Berg (2007), adhocracy culture moderates the relationships and knowledge sharing mediates the relationship of procedural justice and work environment creativity.

\section{FUTURE RECOMMENDATIONS}

In this study convenience sampling is used, future researchers can use other sampling techniques for data collection from the respondents. Future studies can use other outcomes than work environment creativity. Moreover, other moderators and mediators can be examining effecting the relationship of cooperative team environment with work environment creativity and procedural justice with work environment creativity.

\section{REFERENCES}

Amabile, T. M. (1988). A model of creativity and innovation in organizations. Research in Organizational Behavior, 10(1), 123-167. doi:https://doi.org/10.1016/j.riob.2016.10.001

Amabile, T. M., Conti, R., Coon, H., Lazenby, J., \& Herron, M. (1996). Assessing the work environment for creativity. Academy of Management Journal, 39(5), 1154-1184. doi:https://doi.org/10.2307/256995

Angriani, M. R., Ariffin, Z., \& Rahmawati, R. (2017). The influence of psychological climate to the organizational commitment through of job involvement (Study at University Foundation Lecturer Achmad Yani (UVAYA) Banjarmasin). International Journal of Business and Economic Affairs, 2(5), 288-296. doi:https://doi.org/ 10.24088/ijbea-2017-25003

Appu, A. V., \& Sia, S. K. (2017). Creativity at workplace: Role of self-efficacy and harmonious passion. International Journal of Human Resources Development and Management, 17(3-4), 205-219. doi:https://doi.org/10.1504/ ijhrdm.2017.087112

Ayuningrat, M. P., Noermijati., \& Hadiwidjojo, D. (2016). Green product innovation's effect on firm performance of managerial environmental concern and green communication. Journal of Administrative and Business Studies, 2(2), 56-63. doi:https://doi.org/10.20474/jabs-2.2.1

Bernik, B., Azis, Y., Kartini, D., \& Harsanto, B. (2015). Managing innovation of SMEs in creative industry for interactive game subsector and tv and radio subsector based on local wisdom in development of competitiveness business (case study SMEs in bandung). International Journal of Business and Administrative Studies, 1(2), 49-53. doi:https://doi.org/10.20469/ijbas.10001-2

Bhalerao, S. (2016). Role of emotional intelligence in organizational conflict management. International Journal of Business and Administrative Studies, 2(2), 37-43. doi:https://doi.org/10.20469/ijbas.2.10003-2

Cai, W., Lysova, E. I., Khapova, S. N., \& Bossink, B. A. (2018). Does entrepreneurial leadership foster creativity among employees and teams? The mediating role of creative efficacy beliefs. Journal of Business and Psychology, 5(10), 1-15. doi:https://doi.org/10.1007/s10869-018-9536-y

Cameron, K. S., \& Quinn, R. E. (1999). Diagnosing and changing organisational culture. Reading, MA.

Evers, A., van Vliet-Mulder, J. v., \& Groot, C. d. (2000). Documentation of tests and test research in the Netherlands. Assen, Netherlands: Koninklijke Van Gorcum BV.

Ford, C. M., \& Ogilvie, D. (1996). The role of creative action in organizational learning and change. Journal of Organizational Change Management, 9(1), 54-62. doi:https://doi.org/10.1108/09534819610107321

Greenberg, J. (1990). Organizational justice: Yesterday, today, and tomorrow. Journal of Management, 16(2), 399-432. doi:https://doi.org/10.1177/014920639001600208 
Lind, E. A., \& Tyler, T. R. (1988). The social psychology of procedural justice. New York, NY: Springer Science \& Business Media.

Moorman, R. H., Niehoff, B. P., \& Organ, D. W. (1993). Treating employees fairly and organizational citizenship behavior: Sorting the effects of job satisfaction, organizational commitment, and procedural justice. Employee Responsibilities and Rights Journal, 6(3), 209-225. doi:https://doi.org/10.1007/bf01419445

Oetomo, H. W., Satrio, B., \& Lestariningsih, M. (2016). The leadership style as moderating, influence of compensation, Organizational Citizenship Behaviour (OCB), and stress towards intention to quit. International Journal of Business and Economic Affairs, 1(1), 6-12. doi:https://doi.org/10.24088/ijbea-2016-11002

Oldham, G. R., \& Cummings, A. (1996). Employee creativity: Personal and contextual factors at work. Academy of Management Journal, 39(3), 607-634. doi:https://doi.org/10.2307/256657

Organ, D. W. (1997). Organizational citizenship behavior: It's construct clean-up time. Human Performance, 10(2), 85-97. doi:https://doi.org/10.1207/s15327043hup1002_2

Rousseau, D. M. (1989). Psychological and implied contracts in organizations. Employee Responsibilities and Rights Journal, 2(2), 121-139. doi:https://doi.org/10.1007/bf01384942

Saputri, M. E., \& Mulyaningsih, H. D. (2016). Blue ocean strategy for creating value innovation: A study over kedai digital in Yogyakarta, Indonesia. Journal of Administrative and Business Studies, 1(1), 14-20. doi:https://doi.org/ 10.20474/jabs-1.1.3

Schepers, P., \& Van den Berg, P. T. (2007). Social factors of work-environment creativity. Journal of Business and Psychology, 21(3), 407-428. doi:https://doi.org/10.1007/s10869-006-9035-4

Shalley, C. E., \& Gilson, L. L. (2004). What leaders need to know: A review of social and contextual factors that can foster or hinder creativity. The Leadership Quarterly, 15(1), 33-53. doi:https://doi.org/10.1016/ j.leaqua.2003.12.004

Stein, M. I. (1974). Stimulating creativity. New York, NY: Academic Press.

Tang, Y., Huang, X., \& Wang, Y. (2017). Good marriage at home, creativity at work: Family-work enrichment effect on workplace creativity. Journal of Organizational Behavior, 38(5), 749-766. doi:https://doi.org/10.1002/job.2175

Thibaut, J., \& Walker, L. (1975). Procedural justice. Hillsdale, NJ: Lawrence Erlbaum.

Tierney, P., Farmer, S. M., \& Graen, G. B. (1999). An examination of leadership and employee creativity: The relevance of traits and relationships. Personnel Psychology, 52(3), 591-620. doi:https://doi.org/10.1111/ j.1744-6570.1999.tb00173.x

Volmer, J., Richter, S., \& Syrek, C. J. (2018). Creative at each age: Age-related differences in drivers of workplace creativity from an experience sampling study. The Journal of Creative Behavior, 5(1), 12-56. doi:https://doi.org/ 10.1002/jocb. 233

West, M. A., \& Anderson, N. R. (1996). Innovation in top management teams. Journal of Applied Psychology, 81(6), 680-689. doi:https://doi.org/10.1037/0021-9010.81.6.680

Woodman, R. W., Sawyer, J. E., \& Griffin, R. W. (1993). Toward a theory of organizational creativity. Academy of Management Review, 18(2), 293-321. doi:https://doi.org/10.5465/amr.1993.3997517

Zhou, J., \& George, J. M. (2001). When job dissatisfaction leads to creativity: Encouraging the expression of voice. Academy of Management Journal, 44(4), 682-696. doi:https://doi.org/10.5465/amr.1993.3997517

Zhou, J., \& Hoever, I. J. (2014). Research on workplace creativity: A review and redirection. Annual Review Organizational Psychology Organizational Behaviour, 1(1), 333-359. doi:https://doi.org/10.1146/annurev -orgpsych-031413-091226 